\title{
PENGGUNAAN INSTRUMEN DIAGNOSTIK TWO-TIER UNTUK MENGANALISIS MISKONSEPSI ASAM BASA SISWA SMA DAN MA
}

\author{
Achmad Yandi Rahmatul Fajri*, Salamah Agung, Nanda Saridewi \\ Pendidikan Kimia FITK UIN Syarif Hidayatullah, Indonesia \\ Email: yandiahmad545@gmail.com \\ *Corresponden Author
}

\begin{abstract}
ABSTRAK
Penanaman konsep yang benar dalam proses pembelajaran akan menghasilkan mutu pendidikan yang berkualitas (Sa'idah\& Suyono, 2012). Penelitian ini bertujuan untuk menganalisis dan mendeskripsikan penggunaan diagnostik Two-Tier untuk menganalisis miskonsepsi siswa pada materi asam basa di SMA dan MA di kota Serang pada materi asam basa. Metode penelitian ini adalah deskriptif kuantitatif. Data diperoleh dari instrumen yang terdiri dari 16 butir soal dan melibatkan 456 siswa kelas XI dari 5 Sekolah Menengah Atas dan 2 Madrasah Aliyah di Kota Serang. Hasil penelitian menunjukkan bahwa instrumen diagnostik Two-Tier dapat digunakan untuk menganalisis miskonsepsi siswa pada materi asam basa di SMA dan MA dengan kriteria miskonsepsi terjadi pada setiap konsep yang ada pada materi Asam Basa, dengan persentase umum rata-rata persentase siswa kategori miskonsepsi sebanyak $36 \%$ siswa, termasuk kriteria sedikit siswa mengalami miskonsepsi. Miskonsepsi yang ditemukan umumnya karena kurang memahami materi konseptual yang dipelajari di sekolah, menggunakan satu teori untuk semua sifat reaksi asam basa, terjadi pemahaman yang terpisah antara konseptual dengan pemahaman algoritma (perhitungan) dan tidak dapat menghubungkan konsep yang dipelajari dengan keadaan lingkingan sekitar.
\end{abstract}

Kata Kunci: Miskonsepsi; Materi Asam Basa; Tes Diagnostik Two-Tier.

\begin{abstract}
Accurate learning concept in teaching and learning process resulted in quality education (Sa'idah \& Suyono, 2012). This research aimed to analyze and describe the misconception of Senior high school (SMA) and Islamic Senior High School/Madrasah Aliyah (MA) students in Serang city on acid base concept. This research employed quantitative descriptive method. The data was obtained from an instrument consisting of 16 items and involving 456 students of class XI from 5 Senior High School and 2 Madrasah Aliyah in Serang City. The results showed that misconceptions occurred in every concept that existed in the material of Acid Bases, with the general percentage of the average percentage of students misconception category as much as $36 \%$ of students including the criteria of few students experiencing misconceptions. Misconceptions found generally due to lack of understanding of conceptual materials learned in school, using a theory for all the properties of acid-base reactions, separate understanding between the conceptual and the understanding of the algorithm (calculation), and can not relate the concepts studied to the circumstances of the surrounding environment.
\end{abstract}

Key word: Misconception; Two-Tier Diganostic Test; Acid Base Concept.

Copyright (c) 2020 Fajri et al This is an open access article under the $\underline{\mathrm{CC}-\mathrm{BY}}$ license Miskonsepsi Asam Basa Siswa SMA dan MA. JINoP (Jurnal Inovasi Pembelajaran), 6(1). doi: https://doi.org/10.22219/jinop.v6i1.8445 


\section{PENDAHULUAN}

Pada jurusan IPA tingkat SMA dan MA, pelajaran kimia merupakan salah satu materi yang dipelajari oleh siswa. Menurut Tim Pengembang Ilmu Pendidikan UPI (2011) kajian-kajian dalam kimia seperti konsep, hukum, teori dihasilkan bertujuan untuk memahami sifat dan perubahan materi di alam.

Penanaman konsep yang benar dalam proses pembelajaran akan menghasilkan mutu pendidikan yang berkualitas (Sa'idah \& Suyono, 2012). Sedangkan pengukuran mutu pendidikan sulit dilakukan, maka pengukuran mutu dapat dilakukan dengan mengasosiasikan dengan hasil belajar yang dikenal sebagai Ujian Nasional, SBMPTN dapat dijadikan gambaran tentang hasil pendidikan (Tirtarahardja \& Sulo, 2005). Mutu pendidikan dapat dipelajari dari Kota/Kabupaten pada tiap Provinsi di Indonesia. Berdasarkan hasil Ujian Nasional tahun 2015 nilai Kimia di Kota Serang termasuk kategori $\mathrm{C}$ atau cukup yaitu mencapai 57,13 (Puspendik, 2015).

Hasil Ujian Nasional di Kota Serang masih sedikit diatas rata-rata minimum kategori cukup.. Hal tersebut dapat disebabkan karena siswa kurang dalam memahami konsep pada pelajaran Kimia atau salah dalam memahami konsep (miskonsepsi). Miskonsepsi terdapat dalam semua bidang sains (Suparno, 2013).

Salah satu kajian Kimia yang tidak luput dari masalah miskonsepsi adalah "Asam Basa”. Konsep "Asam Basa" ini mempelajari tentang teori-teori Asam Basa dari beberapa ahli , kemampuan siswa dalam memahami materi "Asam Basa" yang abstrak bermacammacam. Siswa yang salah dalam memahami "Asam Basa" dapat menimbulkan miskonsepsi. Peneliti sebelumnya seperti Siswaningsih, Siswaningsih \& Rahmawati (2015) mengingatkan bahwa Miskonsepsi yang terjadi pada siswa harus dihilangkan dan sudah semestinya menjadi perhatian khusus bagi guru serta siswa itu sendiri, karena miskonsepsi bersifat berulang dan melekat kuat pada siswa, akibatnya dapat mengganggu konsepsi berikutnya.

Guru dapat menangani miskonsepsi siswa sesuai yang dibutuhkan setelah menganalisis miskonsepsi tersebut. Hal ini didukung oleh pernyataan Suparno (2013) dalam menghadapi miskonsepsi ada beberapa tindakan yang harus dilakukan seperti mengungkap miskonsepsi pada siswa, mencari penyebab miskonsepsi, mencari perlakuan yang tepat mengatasi miskonsepsi. Jadi langkah awal dalam menindak miskonsepsi "Asam Basa" ialah menganalisis miskonsepsi pada materi "Asam Basa".

Alat yang tepat untuk menganalisis miskonsepsi "Asam Basa" menurut Suparno (2013) yaitu berupa wawancara, pengamatan, peta konsep dan lain-lain. Selain itu juga terdapat instrumen lain seperti Instrumen tes diagnostik two-tier. Instrumen tes diagnostik two-tier mempunyai dua bagian. Bayrak (2013) menjelaskan bahwa bagian pertama adalah soal dengan pilihan ganda untuk memilih jawaban, dan bagian kedua yang merupakan pilihan ganda untuk memilih alasan yang mendasari pilihan jawaban pada bagian pertama.

Instrumen tes diagnostik Two-Tier mempunyai kelebihan dibandingkan dengan Instrumen tes multiple choice pada umumnya yang hanya satu tahap. Kelebihan Instrumen tes diagnostik Two-Tier yaitu salah satunya mengurangi eror pada pengukuran, pada Instrumen tes multiple choice pada umumnya yang memiliki 5 pilihan jawaban terdapat $20 \%$ kesempatan siswa menjawab benar dengan cara menebak, sedangkan pada instrument tes diagnostik Two-Tier terdapat 4\% kemungkinan siswa menjawab benar dengan cara menebak (Tuysuz, 2009). Selain itu penjelasan siswa juga penting bagi guru dalam pengajaran konsep, Tuysuz (2009) menambahkan bahwa dengan adanya pilihan 
alasan, guru dapat mempelajari penjelasan siswa yang mengalami miskonsepsi saat memahami konsep yang diajarkan oleh guru tersebut.

Pada penelitian ini digunakan Instrumen diagnostik two-tier, yang dikembangkan oleh Rositasari, Agung \& Saridewi pada tahun 2014. Instrumen ini terdapat pilihan ganda berlapis dengan lapisan pertama yaitu pilihan ganda biasa untuk menjawab soal yang memiliki pilihan berupa 5 huruf kapital yaitu A, B, C, D, E dan lapisan kedua adalah pilihan alasan untuk melandasi jawaban yang sudah dipilih berupa 5 angka yaitu 1, 2, 3, 4, 5. Dengan demikian, hasil penelitan yang akan didapat berupa pola jawaban hurufangka seperti A5, atau C1. Instrumen ini juga dibagi menjadi soal pada dimensi Konseptual dan soal pada dimensi Prosedural. Butir soal dimensi Konseptual terdapat pada nomor 1 sampai 11 dan 16. Sedangkan butir soal dimensi Prosedural terdapat pada butir soal nomor 12 sampai 15 . Seluruh butir soal tersebut berada pada tingkatan C2 sampai C3 pada ranah kognitif.

Digunakannya instrumen ini selain karena efektif dalam menentukan miskonsepsi pada konsep "Pemisahan Materi” seperti yang dilakukan oleh Tuysuz pada tahun 2009 begitu pula dengan penelitian yang dilakukan oleh Fadiawati dan Liliasari pada tahun 2009 pada materi "Struktur Atom". Sedangkan Instrumen tes diagnostik yang dikembangkan oleh Rositasari et al. (2014) sesuai dengan kompetensi dasar konsep Asam Basa kelas XI dan belum diterapkan dalam skala besar.

Penelitian ini selain untuk mendapat informasi miskonsepsi tentang konsep asam basa pada siswa juga dapat digunakan sebagai rambu-rambu dalam proses pembelajaran selanjutnya agar terhindar dari terjadinya miskonsepsi serupa

\section{METODE}

Metode deskriptif kuantitatif dinilai dapat memenuhi tujuan penelitian ini. Sampel penelitian ini merupakan siswa kelas XI semester genap yang telah belajar Konsep Asam Basa

Sampel penelitian ini dipilih dari beberapa sekolah yang ada di Kota Serang berjumlah 7 sekolah dan total 456 siswa dengan rincian: SMAN 1 Kota Serang sebanyak 115 siswa, SMAN 2 Kota Serang sebanyak 100 siswa, SMAN 3 Kota Serang sebanyak 75 siswa, SMAN 5 Kota Serang sebanyak 37 siswa, SMA Prisma Sanjaya sebanyak 41 siswa, MAN 1 Kota Serang sebanyak 33 siswa, MAN 2 Kota Serang sebanyak 56 siswa,. Pengisian instrumen dilakukan di kelas agar lebih kondusif dan siswa mengerjakan dengan baik dan benar sesuai kemampuan yang dimiliki. Penelitian ini dilakukan dengan memberikan Instrumen kepada seluruh siswa kelas XI yang telah menerima materi asam basa di setiap sekolah. Penelitian ini dilakukan saat kegiatan belajar mengajar sekolah selesai atau istirahat sekolah agar tidak menggangu kegiatan di sekolah

Bentuk deskripsi atau penjelasan respon siswa yang telah dibagi menjadi 3 kategori (Satriana, Yamtinah, Indriyanti \& Wijaya, 2017). Kategori respon siswa sebagai berikut:

Tabel 1. Kategori Pilihan Jawaban Siswa

\begin{tabular}{lcc}
\hline \multicolumn{1}{c}{ Pola Jawaban } & $\begin{array}{c}\text { Kategori } \\
\text { Jawaban }\end{array}$ & Kode \\
\hline Jawaban inti tes benar-alasan benar & Paham Konsep & 3 \\
Jawaban inti tes salah-alasan benar & Miskonsepsi & 2 \\
Jawaban inti tes benar-alasan salah & Miskonsepsi & 1 \\
Jawaban inti tes salah-alasan salah & Tidak Paham & 0 \\
& Konsep & \\
\hline
\end{tabular}


Rentang banyaknya siswa pada kategori miskonsepsi dapat dilihat melalui Tabel 2 yang dirumuskan oleh Haris \& Idrus (2008) seperti Tabel 2:

Tabel 2. Rentang dan Kategori Kesalahan Konsep

\begin{tabular}{cl}
\hline Rentang & Kriteria \\
\hline $0 \%$ & Tidak ada siswa mengalami kesalahan konsep (miskonsepsi) \\
$0 \%<$ kesalahan konsep $\leq 20 \%$ & Sangat sedikit siswa mengalami kesalahan konsep (miskonsepsi) \\
$20 \%<$ kesalahan konsep $\leq 40 \%$ & Sedikit siswa mengalami kesalahan konsep (miskonsepsi) \\
$40 \%<$ kesalahan konsep $\leq 60 \%$ & Cukup banyak siswa mengalami kesalahan konsep (miskonsepsi) \\
$60 \%<$ kesalahan konsep $\leq 80 \%$ & Banyak siswa mengalami kesalahan konsep (miskonsepsi) \\
$80 \%<$ kesalahan konsep $\leq 100$ & Sangat banyak siswa mengalami kesalahan konsep (miskonsepsi) \\
$100 \%$ & Semua siswa mengalami kesalahan konsep (miskonsepsi) \\
\hline
\end{tabular}

Tabel 3 Identitas Soal Diagnostik

\begin{tabular}{cclc}
\hline Konsep & No & Dimensi & Tingkat \\
\hline & 1 & Konseptual & C2 \\
Teori Asam Basa & 2 & Konseptual & C2 \\
& 4 & Konseptual & C3 \\
& 5 & Konseptual & $\mathrm{C} 3$ \\
Kndikator Asam Basa & 6 & Konseptual & $\mathrm{C} 3$ \\
& 7 & Konseptual & $\mathrm{C} 3$ \\
Kekuatan Asam Basa & 10 & Konseptual & $\mathrm{C} 2$ \\
Tetapan Asam Basa & 11 & Konseptual & $\mathrm{C} 2$ \\
& & Konseptual & $\mathrm{C} 2$ \\
Perhitungan Asam Basa & 13 & Konseptual & $\mathrm{C} 3$ \\
pH dalam Lingkungan & 14 & Konseptual & $\mathrm{C} 3$ \\
& 15 & Prosedural & $\mathrm{C} 2$ \\
& 16 & Prosedural & $\mathrm{C} 2$ \\
& & Prosedural & $\mathrm{C} 2$ \\
& & Prosedural & $\mathrm{C} 2$ \\
\end{tabular}

Soal tes diagnostik terbagi menjadi enam konsep berbeda meliputi (1) Teori Asam Basa (ada 8 soal dimensi konseptual, dengan 4 soal tingkat C2 dan 4 soal tingkat C3), (2) Indikator Asam Basa (ada 1 soal dimensi konseptual pada tingkat C2), (3) Kekuatan Asam Basa (ada 1 soal dimensi konseptual pada tingkat C2), (4) Tetapan Asam Basa (ada 1 soal dimensi konseptual pada tingkat C3), (5) Perhitungan Asam Basa ( ada 4 soal dimensi procedural dengan tingkat $\mathrm{C} 2$ ) dan (6) $\mathrm{pH}$ dalam Lingkungan (ada 1 soal dimensi konseptual dengan tingkat $\mathrm{C} 3$ ). Berdasarkan tabel diatas, soal diagnostik cenderung banyak berada pada ranah konseptual dengan tingkatan C2 sampai C3. Dalam taksonomi Bloom, tingkat C2 merupakan Berpikir Tingkat Rendah sedangkan C3 merupakan Berpikir Tingkat Tinggi. Dimensi prosedural soal tes lebih abstrak daripada dimensi konseptual (Gunawan \& Palupi, 2012). Dengan demikian, membutuhkan pemahaman lebih untuk mengerjakan soal ranah prosedural daripada soal ranah konseptual dan C2 dimensi konseptual tidak sama dengan $\mathrm{C} 2$ dimensi prosedural. 


\section{HASIL DAN PEMBAHASAN}

Analisis miskonsepsi asam basa siswa didasari oleh respon siswa terhadap instrumen tes yang digunakan. Data jawaban siswa juga dipaparkan dalam bentuk persentase.

Soal tes diagnostik yang digunakan dalam penelitian ini adalah instrument tes hasil pengembangan Rositasari tahun 2014 berjumlah 16 butir soal pilihan ganda beralasan. Secara singkat identitas soal tes dipaparkan pada tabel 3.

Hasil penelitian ini ditampilkan pada tabel 4 dalam bentuk persentase siswa kategori Miskonsepsi beserta kriteria sesuai pada tabel 2.

Tabel 4 Persentase Siswa

\begin{tabular}{ccccc}
\hline Konsep & No & Miskonsepsi & Paham & Tidak Paham \\
\hline \multirow{2}{*}{ Teori Asam Basa } & 1 & $28 \%$ & $54 \%$ & $18 \%$ \\
& 2 & $30 \%$ & $25 \%$ & $44 \%$ \\
& 3 & $38 \%$ & $34 \%$ & $28 \%$ \\
& 4 & $30 \%$ & $8 \%$ & $62 \%$ \\
Indikator Asam Basa & 5 & $49 \%$ & $25 \%$ & $26 \%$ \\
Kekuatan Asam Basa & 6 & $27 \%$ & $25 \%$ & $48 \%$ \\
Tetapan Asam Basa & 7 & $43 \%$ & $40 \%$ & $17 \%$ \\
& 10 & $29 \%$ & $32 \%$ & $38 \%$ \\
Perhitungan Asam Basa & 11 & $38 \%$ & $35 \%$ & $28 \%$ \\
& 12 & $32 \%$ & $9 \%$ & $59 \%$ \\
pH dalam Lingkungan & 13 & $28 \%$ & $35 \%$ & $28 \%$ \\
& 14 & $29 \%$ & $23 \%$ & $50 \%$ \\
& 15 & $39 \%$ & $20 \%$ & $51 \%$ \\
& 16 & $39 \%$ & $7 \%$ & $54 \%$ \\
& & $54 \%$ & $36 \%$ & $52 \%$ \\
& & & & $10 \%$ \\
\hline
\end{tabular}

Miskonsepsi ditemui pada setiap butir soal dengan rentang persentase $27 \%$ hingga 54\%. Lebih dari 50\% mengalami miskonsepsi pada butir soal 16, sedangkan pada butir soal nomor 6 memiliki persentase siswa miskonsepsi hanya mencapai 27\% paling sedikit daripada butir soal yang lain.

Hasil data analisis urutan kesulitan soal didapat dari hasil perhitungan program RASCH pada item measure. Menurut Sumintono (2015) tingkat kesulitan butir-butir soal dikelompokkan dengan cara hasil kombinasi dari nilai rata-rata logit dan standar deviasi yang ada pada item measure. Hasilnya dibagi menjadi 4 tingkat kesulitan soal yaitu: Sangat sulit, sulit, mudah, sangat mudah (hlm. 70). Dalam hal ini, standar deviasi yang didapat oleh perhitungan program RASCH yaitu 0,37 dengan nilai rata-rata logit 0,00 . Butir soal dibagi menjadi 4 kelompok yaitu sangat sukar (lebih besar dari $+0,37 \mathrm{SD}$ ), sukar $(0,00$ logit $+0,37 \mathrm{SD})$, mudah $(0,00$ logit $-0,37 \mathrm{SD})$, dan sangat mudah (kurang dari $0,37 \mathrm{SD})$. Berikut urutan kesulitan soal yang didapat dari program RASCH. 
Tabel 5 Data Kesulitan Soal Berdasarkan Respon Siswa

\begin{tabular}{ccl}
\hline Nomor soal & Measure & \multicolumn{1}{c}{ Keterangan } \\
\hline 14 & 0,56 & Sangat sulit \\
4 & 0,48 & Sangat sulit \\
15 & 0,47 & Sangat sulit \\
10 & 0,41 & Sangat sulit \\
13 & 0,19 & Sulit \\
6 & 0,17 & Sulit \\
12 & 0,16 & Sulit \\
2 & 0,10 & Sulit \\
5 & $-0,10$ & Mudah \\
8 & $-0,14$ & Mudah \\
9 & $-0,24$ & Mudah \\
11 & $-0,25$ & Mudah \\
3 & $-0,25$ & Mudah \\
16 & $-0,38$ & Sangat mudah \\
7 & $-0,46$ & Sangat mudah \\
1 & $-0,74$ & Sangat mudah \\
\hline
\end{tabular}

Tabel 5 menunjukkan bahwa siswa menilai instrumen tes yang dikerjakan memiliki tingkat kesulitan yang beragam, dan walaupun dalam konsep yang sama siswa merasakan kesulitan yang berbeda seperti konsep teori Asam Basa soal nomor 4 termasuk soal yang sangat sulit dikerjakan, dan soal nomor 6, 2 termasuk soal yang sulit dan sisanya terdapat pada kategori Mudah dan Sangat Mudah. Sedangkan untuk konsep perhitungan asam basa dinilai sulit dikerjakan oleh siswa dapat dilihat dari soal pada konsep tersebut tidak ada pada kategori soal Mudah atau Sangat Mudah.

Tabel 6 Persentase Siswa Dengan Pola Jawaban Miskonsepsi Terbanyak Pada Tiap Soal

\begin{tabular}{ccccc}
\hline No & \% & Pola Jawaban & Kriteria & Kode \\
\hline 1 & 28 & A5 & Sedikit & 2 \\
2 & 30 & C2 & Sedikit & 1 \\
3 & 38 & D1 & Sedikit & 1 \\
4 & 30 & E5 & Sedikit & 2 \\
5 & 49 & E1 & Cukup Banyak & 1 \\
6 & 27 & C4 & Sedikit & 1 \\
7 & 43 & B2 & Cukup Banyak & 1 \\
8 & 29 & E5 & Sedikit & 1 \\
9 & 38 & C3 & Sedikit & 1 \\
10 & 32 & C4 & Sedikit & 2 \\
11 & 37 & C3 & Sedikit & 1 \\
12 & 28 & D3 & Sedikit & 1 \\
13 & 29 & A5 & Sedikit & 2 \\
14 & 39 & C2 & Sedikit & 1 \\
15 & 39 & A4 & Sedikit & 1 \\
16 & 54 & A5 & Cukup Banyak & 1 \\
\hline
\end{tabular}

Kriteria yang mendominasi ialah sedikit siswa mengalami miskonsepsi. Siswa miskonsepsi didominasi oleh kode 1 (Jawaban Inti Benar-Jawaban Alasan Salah). 
Miskonsepsi terbanyak pada tabel 6 terdapat pada butir soal 16 yang dinilai Sangat Mudah bagi siswa. lalu sangat sedikit siswa miskonsepsi pada butir soal nomor 6 yang dirasa Sulit bagi siswa. Fenomena ini dapat saja terjadi berkaitan dengan Tabel 1 yaitu Kategori Jawaban siswa dibagi menjadi beberapa kode yang dimasukkan ke dalam program RASCH, dan hasil perhitungan ini selain memperhitungkan persentase siswa tiap kategori pemahaman (Paham, Miskonsepsi, Tidak Paham) juga Standar Deviasi dan logit yang dapat dijadikan sebuah landasan sebuah soal termasuk mudah walaupun memiliki siswa miskonsepsi lebih dari 50\%. Di beberapa soal lain juga ditemui bahwa walau Cukup Banyak siswa kategori Miskonsepsi, tapi dirasakan Sangat Mudah bagi siswa untuk mengerjakan soal. Hal ini dapat menunjukkan bahwa tingkat kesulitan soal tidak termasuk dalam penyebab siswa miskonsepsi.

\section{Konsep Asam Basa}

Konsep ini mengenai beberapa teori yang berlaku dalam Bab Asam Basa. Miskonsepsi siswa pada konsep ini bermacam-macam tergantung pada subkonsepnya masing-masing. Secara garis besar siswa kategori Miskonsepsi menunjukkan belum familiar dengan teori-teori Asam Basa (Muchtar \& Harizal 2012). Miskonsepsi yang dibahas adalah miskonsepsi dengan persentase siswa terbanyak dari tiap kemungkinan di setiap konsep dan subkonsepnya.

\section{Subkonsep Teori Asam Basa Arrhenius}

Subkonsep ini terdiri dari tiga butir soal nomor yaitu 1, 7 dan 8 . Ketiga butir soal tersebut menuntut pemahaman siswa pada Teori Asam Basa Arrhenius.

Miskonsepsi pertama karena salah dalam memberikan jawaban. Jawaban siswa "Asam terionisasi menghasilkan ion $\mathrm{H}^{++}$"dinilai kurang tepat dikarenakan jawaban tersebut adalah sebagian dari teori dari konsep Asam Basa Arrhenius. Siswa miskonsepsi hanya mampu menjelaskan larutan asam Arrhenius saja dan tidak dapat menjelaskan larutan basa Arrhenius (Sudarmo, 2009).

Miskonsepsi selanjutnya adalah siswa yang memilih alasan yang tidak tepat. Alasan yang diberikan siswa ialah "Senyawa Asam Basa menurut Lewis mengalami serah terima elektron bebas tetapi terbatas pada ada atau tidaknya proton $\left(\mathrm{H}^{+}\right)$". Siswa menggunakan ada atau tidaknya proton $\left(\mathrm{H}^{+}\right)$sebagai landasan teori Lewis. Dari sudut pandang ini dapat ditafsirkan bahwa siswa miskonsepsi memahami teori Arrhenius lebih sempurna daripada teori Lewis.

\section{Subkonsep Teori Asam Basa Bronsted-Lowry}

Subkonsep teori asam basa Bronsted-Lowry terdapat pada butir soal nomor 2 . Miskonsepsi yang ditemukan yaitu karena salah saat memilih alasan. Siswa memilih alasan "Menurut Bronsted-Lowry, sifat asam atau basa didasari oleh serah terima elektron". Alasan tersebut tidaklah sesuai dengan teori Asam Basa Bronsted-Lowry. Tertukar istilah "proton" yang digunakan pada teori Bronsted-Lowry dengan penggunaan istilah "elektron" pada teori Lewis yang sejalan dengan penelitian Rositasari et al. (2014) karena siswa tidak konsisten dalam memilih jawaban dan tidak dapat membedakan istilah "proton" dan "elektron" yang digunakan.

\section{Subkonsep Reaksi Asam Basa Arrhenius}

Subkonsep reaksi asam basa Arrhenius terdapat pada butir soal 3. Miskonsepsi ditemukan karena kesalahan saat memilih alasan. Pilihan alasan siswa kurang tepat 
karena "Ion-ionnya terionisasi menjadi Kation dan Anion" merupakan pernyataan yang terlalu umum. Reaksi pada asam basa Bronsted-Lowry juga dapat menghasilkan kationanion

\section{Subkonsep Reaksi Asam Basa Lewis}

Diwakilkan oleh butir soal nomor 4. Indikator pencapaian kompetensi butir soal ini yaitu menuliskan reaksi asam dan basa berdasarkan teori Lewis. Soal nomor 4 menggunakan persamaan reaksi yang terdapat pada soal nomor 3 .

Siswa kategori Miskonsepsi memilih jawaban yang salah berupa " $\mathrm{H}_{2} \mathrm{O}(l)+\mathrm{H}_{2} \mathrm{O}_{(l)}$ $\rightleftharpoons \mathrm{H}_{3} \mathrm{O}^{+}{ }_{(a q)}+\mathrm{OH}_{(a q)}^{-}, \mathrm{NH}_{3(g)}+\mathrm{HNO}_{3(a q)} \rightleftharpoons \mathrm{NH}_{4}{ }_{(a q)}+\mathrm{NO}_{3^{-}}{ }_{(a q)}$ " Miskonsepsi dikarenakan menganggap reaksi pilihan siswa merupakan reaksi Asam Basa Lewis. Sebenarnya reaksi tersebut merupakan reaksi Asam Basa Bronsted-Lowry dan reaksi autoionisasi air adalah contoh dari reaksi Asam Basa Bronsted-Lowry. Reaksi autoionisasi dijelaskan oleh Petrucci (2009) reaksi terjadi karena molekul air dapat saling bereaksi yang salah satunya bersifat basa.

\section{Subkonsep Reaksi Asam Basa Bronsted-Lowry}

Subkonsep ini terdiri dari dua butir soal nomor yaitu 5 dan 6. Miskonsepsi siswa yang ditemukan ialah memilih alasan yang kurang tepat berupa " $\mathrm{H}_{2} \mathrm{CO}_{3}$ menerima proton $\left(\mathrm{H}^{+}\right)$dari $\mathrm{H}_{2} \mathrm{O}$ ". Menunjukkan bahwa siswa masih bingung dalam menentukan zat pasangan asam basa konjugasi. Siswa menganggap bahwa $\mathrm{H}_{2} \mathrm{CO}_{3}$ merupakan donor proton $\left(\mathrm{H}^{+}\right)$dari $\mathrm{H}_{2} \mathrm{O}$. Sebenarnya $\mathrm{H}_{2} \mathrm{CO}_{3}$ merupakan hasil reaksi dan yang menerima proton $\left(\mathrm{H}^{+}\right)$adalah $\mathrm{HCO}_{3}$-dari $\mathrm{H}_{2} \mathrm{O}$.

Miskonsepsi lainnya karena siswa salah dalam memilih alasan. Alasan yang dipilh yaitu " $\mathrm{SO}_{4}{ }^{2-}$ bertindak sebagai asam konjugasi dan $\mathrm{H}_{2} \mathrm{O}$ sebagai basa". Menganggap bahwa " $\mathrm{SO}_{4}{ }^{2-}$ bertindak sebagai asam konjugasi sedangkan $\mathrm{H}_{2} \mathrm{O}$ sebagai basa". Pernyataan ini mengindikasikan bahwa siswa kesulitan untuk menentukan zat yang menjadi pasangan asam basa konjugasi. Peneliti terdahulu yang menemukan kasus serupa ialah Meylindra, Ibnu \& Sulistina (2013) bahwa siswa sulit membedakan antara asam konjugasi dan basa konjugasi.

\section{Konsep Indikator Asam Basa}

Konsep Indikator Asam Basa diwakili oleh butir soal nomor 9.Indikator pencapaian kompetensi yaitu mengidentifikasikan sifat larutan asam dan basa dengan berbagai indikator.

Siswa kategori Miskonsepsi salah dalam memilih alasan. Alasan berupa "Semakin terang warna indikator, maka akan semakin asam dan semakin gelap warna indikator maka akan semakin basa" merupakan alasan yang tidak tepat karena terang gelap suatu lakmus atau indikator $\mathrm{pH}$ tidak menjelaskan perbedaan $\mathrm{pH}$, namun trayek $\mathrm{pH}$ yang berbedalah penyebab perubahan warna pada lakmus seperti yang dijelaskan oleh Zumdahl (2007) di bukunya mengurutkan trayek pH asam yaitu 0 sampai 6, 7 adalah netral dan basa 8 sampai 14; Nivaldo (2007) juga menjelaskan larutan asam dapat merubah warna lakmus biru menjadi merah dan larutan basa dapat merubah warna lakmus merah menjadi biru.

\section{Konsep Kekuatan Asam Basa}

Konsep Kekuatan Asam Basa diwakili oleh butir soal nomor 10. Indikator soal yaitu menyimpulkan hubungan antara beberapa jenis larutan terhadap kekuatan asam dan basa. 
Siswa kategori Miskonsepsi salah dalam memilih jawaban. Jawaban siswa kategori miskonsepsi salah dikarenakan memilih "nilai $\left[\mathrm{H}^{+}\right]$larutan basa lebih dari $10^{-7}$ ", pernyataan tersebut tidak benar karena seharusnya nilai dari konsentrasi ion hidrogen atau $\left[\mathrm{H}^{+}\right]$pada larutan basa kurang dari $10^{-7}$. Berdasarkan jawaban, siswa miskonsepsi terlihat memiliki masalah pada pemahaman tentang pengaruh konsentrasi ion $\mathrm{H}^{+}$terhadap sifat keasaman atau kebasaan suatu larutan. Silberberg (2007) dan Rositasari et al. (2014) menjelaskan pada larutan basa seharusnya nilai konsentrasi ion Hidrogen akan semakin kecil, sebaliknya, nilai konsentrasi ion Hidroksida akan semakin besar.

\section{Konsep Tetapan Ionisasi Asam Basa}

Konsep Kekuatan Asam Basa diwakili oleh butir soal nomor 11. Soal ini menyediakan gambar 2 buah larutan asam dengan beda kekuatan asamnya namun memiliki konsentrasi yang sama. Indikator pencapaian kompetensi yaitumenjelaskan perbedaan asam kuat dan lemah serta basa kuat dan lemah berdasarkan ionisasinya di dalam air.

Siswa kategori Miskonsepsi sudah salah memberikan alasan. Alasan siswa kategori Miskonsepsi keliru saat memilih "Asam asetat memiliki jumlah atom Hidrogen lebih banyak dibandingkan dengan Asam klorida". Siswa kategori Miskonsepsi memilih alasan ini menunjukkan bahwa siswa masih menerapkan teori Arrhenius saat menjawab ionisasi Asam Basa dengan berpaku pada atom $\mathrm{H}$ sebagai pengenal sifat larutan asam (Muchtar \& Harizal, 2012) dan menghitung jumlah atom H untuk menentukan kekuatan pada larutan tersebut (Artdej, Ratanaroutai, Coll \& Thongpanchang, 2010).

\section{Konsep Perhitungan Asam Basa}

Konsep ini terdiri dari 4 butir soal dimulai dari butir soal nomor 12 sampai butir soal nomor 15.

Pada konsep Pehitungan Kimia hampir setiap soalnya, peserta didapati salah dalam memilih alasan yang merupakan pengetahuan konseptual dan cenderung tepat saat memberikan jawaban yang merupakan hasil dari perhitungan. Sejalan dengan hal tersebut, Muntari (2010) menyatakan bahwa kemampuan siswa dalam memecahkan masalah algoritmik terpisah dengan pemahaman konseptual kimia.

Miskonsepsi pertama ditemukan pada Konsep Perhitungan Kimia saat siswa salah dalam memilihalasan walau jawabannya tepat. Jawaban siswa adalah "11" untuk hasil perhitungan menentukan $\mathrm{pH}$ dari larutan basa lemah. Berbeda dengan alasan yang dipilih siswa kategori Miskonsepsi untuk melandasi jawaban tersebut. Jika siswa menghitung dengan cermat, maka alasan"pOH $=-\log 10^{-11}$ " tidaklah tepat. Perhitungan yang tepat akan menghasilkan $\mathrm{pOH}=-\log 1 \times 10^{-3}$, sedangkan $-\log 10^{-11}$ adalah nilai $\mathrm{pH}(\mathrm{pH}=-\log$ $\left.10^{-11}\right)$. Sesuai dengan rumus " $\mathrm{pOH}=-\log \left[\mathrm{OH}^{-}\right]$" konsentrasi ion $\mathrm{OH}^{-}$yang tepat sebesar $1 \times 10^{-3}$ Molar.

Miskonsepsi lain yang ada di siswa berupa benar saat memberikan jawaban namun salah dalam memberikan alasan. Jawaban siswa sudah tepat saat memilih " $1 \times 10^{-3}$ " untuk menentukan derajat ionisasi suatu larutan asam seperti pada Lampiran 5. Ini menunjukkan bahwa siswa untuk matematis sudah paham dan mengerjakan soal dengan baik. Namun berbeda saat memilih alasan. Pilihan alasan berupa jebakan disediakan bagi siswa yang memilih alasan dengan asal juga mendapatkan hasil. Siswa miskonsepsi dengan asal memilih rumus yang disediakan pada pilihan alasan pada butir soal 14. Alasan yang siswa berupa " $\alpha=\frac{K a}{[H]^{+}}$" tidaklah sesuai dengan kaidah perhitungan kimia. Rositasari et al. (2014) 
mengungkapkan siswa miskonsepsi memilih pilihan rumus tanpa mengkaji kembali hubungan antara reaksi kesetimbangan asam terhadap derajat ionisasi asam. Hubungan

yang benar yaitu " $\alpha=\sqrt{\frac{K_{a}}{M_{\text {Larutan Asam }}}}$ ", namun karena hubungan tersebut tidak ada dalam pilihan alasan yang terdapat pada soal maka alasan yang melandasi jawaban soal ini adalah "Konsentrasi larutan asam tersebut adalah $10 \mathrm{M}$ ".

Miskonsepsi lainnya berupa belum memahami rumus dalam menentukan konsentrasi larutan. Siswa menjawab bahwa "0,2 gram" adalah nilai yang tepat untuk mendapatkan larutan $\mathrm{NaOH}$ dengan $\mathrm{pH} 12$ sebanyak 500ml. Namun untuk alasan yang dipilih siswa yaitu "Konsentrasi $\left[\mathrm{OH}^{-}\right]$didasari oleh mol larutan per volume larutan" tidaklah tepat. Bila dikaji tentang perhitungan Molaritas, maka alasan yang benar adalah konsentrasi larutan didasari oleh nilai mol per 1 liter pelarut. Akan tetapi alasan yang mendasari jawaban yang benar untuk soal ini ialah "Mol NaOH adalah 5 X $10^{-3}$ ".

\section{Konsep pH dalam Lingkungan}

Konsep $\mathrm{pH}$ dalam Lingkungan diwakili oleh butir soal nomor 16. Indikator pencapaian kompetensi yaitumenjelaskan penggunaan konsep $\mathrm{pH}$ dalam lingkungan.

Siswa kategori Miskonsepsi sudah memberikan alasan yang tidak tepat. Siswa belum dapat menentukan alasan yang tepat karena memilih "Perubahan nilai $\mathrm{pH}$ air sungai kemungkinan disebabkan oleh limbah pabrik kimia yang mengandung senyawa Asam klorida yang cukup tinggi sehingga mengurangi kualitas air". Dengan kenaikan nilai $\mathrm{pH}$ pada ilustrasi bukanlah larutan asam yang mencemari lingkungan sungai, melainkan larutan basa. Konsep asam basa berkaitan erat dengan konsep yang lain (Fitriyah \& Sukarmin, 2013).

Siswa kategori miskonsepsi butir soal nomor 16 kemungkinan kurang mampu dalam menghubungkan konsep asam basa dengan contoh dikeadaan yang nyata tentang menentukan perubahan $\mathrm{pH}$. Hal ini seperti di temukan oleh Rositasari et al. (2014) beberapa tahun lalu bahwa miskonsepsi terjadi karena siswa tidak dapat menghubungkan konsep dengan keadaan sekitar kehidupan nyata. Muchtar \& Harizal (2012) menambahkan bahwa siswa kategori miskonsepsi mempertahankan dirinya untuk tidak menghubungkan konsep yang telah dipelajari dengan konsep yang lain selama proses belajar Asam Basa.

\section{SIMPULAN}

Berdasarkan tujuan penelitian ini, yaitu untuk Menganalisis miskonsepsi kimia di SMA dan MA di Kota Serang pada materi Asam Basa dan betujuan pula untuk mengetahui persentase jumlah siswa yang mengalami miskonsepsi kimia di SMA/MA seKota Serang dengan menggunakan Instrumen tes diagnostik Two-Tier, dapat disimpulkan bahwa Instrumen Tes Diagnostik Two-Tier dapat digunakan untuk menganalisis miskonsepsi siswa pada materi asam basa disemua konsep. Siswa kategori Miskonsepsi ditemui pada semua butir soal tes yang diujikan. Secara umum rata-rata persentase siswa baik kategori Paham Konsep (26\%), Miskonsepsi (36\%) dan Tidak Paham Konsep (38\%). Siswa kategori miskonsepsi termasuk kriteria jumlah siswa yang sedikit dengan kriteria miskonsepsi benar memberikan jawaban namun salah dalam memilih alasan. Miskonsepsi yang ditemukan umumnya karena kurang memahami materi konseptual yang dipelajari di sekolah, menggunakan satu teori untuk semua sifat reaksi asam basa, terjadi pemahaman yang terpisah antara konseptual dengan pemahaman algoritma 
(perhitungan) dan tidak dapat menghubungkan konsep yang dipelajari dengan keadaan lingkingan sekitar

\section{DAFTAR PUSTAKA}

Artdej, R., Ratanaroutai, T., Coll, K. R., \& Thongpanchang, T. (2010). Thai Grade 11 Students' alternative conception for acid-base chemistry. $b$

Bayrak, B. K. (2013). Using two-tier test to identify primary students' conceptual understanding and alternative conceptions in acid base. Mevlana International Journal of Education, 3(2), 19-26.

Fadiawati, N., \& Liliasari, (2009). Konsepsi Mahasiswa Pendidikan Kimia Tahun Pertama Tentang Struktur Atom, Prosiding Seminar Nasional Penelitian, Pendidikan dan Penerapan MIPA, fakultas MIPA Universitas Negeri Yogyakarta, Yogyakarta.

Fitriyah, N., \& Sukarmin, (2013). Penerapan media animasi untuk mencegah miskonsepsi pada materi pokok asam basa di Kelas XI SMAN 1 Menganti Gresik, Unesa Journal of Chemical Education, 2(3), 73-84.

Gunawan, I., \& Palupi, A. R. (2012). Taksonomi Bloom - Revisi ranah kognitif: kerangka landasan untuk pembelajaran pengajaran, dan penilaian

Haris, M., \& Idrus, S. W. A. (2008). Analisis kesulitan belajar ikatan kimia ditinjau dari kesalahan konsep siswa kelas X SMA Negeri 3 Mataram. Jurnal Pijar MIPA. 6(2), 77-80.

Meylindra, I., Ibnu, Suhadi., \& Sulistina, O. (2013). Identifikasi pemahaman konsep larutan asam basa melalui gambar mikroskopik pada Siswa Kelas XI IPA SMA Negeri 5 Malang. 2(2).

Muchtar, Z., \& Harizal. (2012). Analyzing of students' misconceptions on acid-base chemistry at Senior High School in Medan. Journal Education and Practice, 3(15), $65-74$

Muntari. (2010). Peningkatan pemahaman kimia melalui paduan pembelajaran kooperatif dah pemecahan masalah kimia dengan teknik pathway. Jurnal Ilmu Pendidikan, 17(2). 130-137.

Nivaldo, J. T. (2007). Chemistry in focus a molecular view of our world. Boston: Cengage Learning.

Petrucci, R. H. \& Suminar. (2009). Kimia dasar prinsip dan terapan modern (edisi ke-9). Jakarta: Erlangga.

Puspendik. 2015.Rekap hasil Ujian Nasional (UN) tingkat SMA dan MA 2014/2015.Diakses $14 \quad$ Desember $2016 \quad$ on-line https://puspendik.kemdikbud.go.id/hasil-un/.

Rositasari, D., Saridewi, N., \& Agung, S. (2014). Pengembangan tes diagnostik two-tier untuk mendeteksi miskonsepsi siswa SMA pada topik Asam Basa. Edusains, 6(2), 163-168.

Sa'idah, G., \& Suyono. (2012). penerapan strategi pembelajaran PDEODE (predict, discuss, explain, observe, discuss, explain) untuk mereduksi miskonsepsi siswa pada materi pokok hidrolisis garam di SMAN 2 Bojonegoro. Prosiding Seminar Nasional Kimia Unesa, Surabaya.

Satriana, T., Yamtinah, S., Indriyanti, N. C., \& Wijaya, S. (2017). Pengembangan instrumen Computerized Two Tier Multiple Choice (CTTMC) untuk mendeteksi miskonsepsi siswa pada materi kesetimbangan kimia. Seminar Nasional Pendidikan Sains Universitas Sebelas Maret, Surakarta. 
Silberberg, M. S. (2007). Principles of general chemistry. Pennsylvania: McGraw-Hill Higher Education.

Siswaningsih, W., Hernani \& Rahmawati, T., (2015). Profil miskonsepsi siswa SMA pada materi hidrokarbon menggunakan instrumen tes diagnostik pilihan ganda bertingkat. Jurnal Penelitian Pendidikan Kimia, 1(2), 200-206.

Sudarmo, U. (2009). Miskonsepsi Siswa SMA Terhadap Konsep-Konsep Kimia. Prosiding Seminar Nasional Kimia dan Pendidikan Kimia, Surabaya.

Sumintono, B. (2015) Pemodelan rasch pada asesmen pendidikan: Suatu pengantar. In: Konferensi Guru dan Dosen Nasional (KGDN) 2015 , 8 November 2015, Aula Auditorium Universitas Sumatera Utara (USU) Medan, Indonesia. Suparno, P. (2013). Miskonsepsi dan perubahan konsep dalam pendidikan fisika. Jakarta: Gramedia Widiasarana Indonesia.

Tim Pengembang Ilmu Pendidikan FIP-UPI (2011). Ilmu dan aplikasi pendidikan bagian III pendidikan disiplin ilmu. Bandung: Tim UPI.

Tirtarahadja, U., Sulo, S. L., (2005). Pengantar Pendidikan. Jakarta: Rineka Cipta.

Tuysuz, C. (2009). Development of two-tier diagnostic instrument and assess students' understanding in chemistry, Scientific Research and Essay, 4(6), 626-631.

Zumdahl, S. S., \& Zumdahl S. A. (2007). Chemistry ( $7^{\text {th }}$ edition). New York: Houghton Miffllin Company. 